\title{
ANALISA KEBUTUHAN AIR BERSIH PADA DI KOTA BINJAI SUMATERA
} UTARA

\author{
Salomo Simanjuntak ${ }^{1}$, Eben Oktavianus Zai ${ }^{2}$, \\ Parto Oktavianus Sihombing ${ }^{3}$ \\ Fakultas Teknik Sipil Universitas HKBP Nommensen \\ Email: salomojuntak679@yahoo.co.id ${ }^{1}$, ebenzay5@gmail.com ${ }^{2}$, \\ parto_sihombing@yahoo.co.id ${ }^{3}$
}

\begin{abstract}
Human life is very dependent on the fact of good quality air which is called clean water. Clean water is one type of water-based resource that is of good quality and is commonly used by humans for consumption or in carrying out their daily activities including sanitation. The most important thing is clean water is a basic human need that affects human health.

Binjai City is a city with a dense population of 283,362 people in 2020 , including a small city with a usage of 100 liters / person / day. This requires an analysis of the need for clean water that can be used effectively, efficiently and sustainably. This analysis will require data: the total population obtained from the Central Bureau of Statistics and the existing clean water capacity will be obtained from PDAM Tirtasari as well as literature studies or direct links to related parties regarding the existence of clean water in the city of Binjai.

The need for clean water is divided into domestic water needs and non-domestic water needs in which there are social, commercial, industrial, and government agency needs. This need will be projected until 2025 so that Binjai city needs to build a new water treatment plant.
\end{abstract}

Keywords: Clean Water, Population Growth And Water Needs

\section{PENDAHULUAN}

\subsection{Latar Belakang}

Air merupakan sumber kehidupan, tidak hanya bagi manusia, makhluk hidup yang lain juga sangat membutuhan air. Bahkan dapat dipastikan tanpa pengembangan sumber daya air konsisten peradaban manusia tidak akan mencapai tingkat yang dinikmati sampai saat ini. Oleh karena itu, pengembangan dan pengolahan sumber daya air merupakan dasar peradaban manusia (“Sunaryo, dkk. 2005”). Bagi manusia, air bersih berperan penting dalam berbagai macam bentuk kegiatan sehari-hari. Baik itu kebutuhan air untuk domestik, industry (komersial) dan lain-lainnya.

Dalam Perpres Nomor 33 tahun 2011 tentang Kebijakan Nasional Pengelolaan Sumber Daya Air disebutkan bahwa dalam pemenuhan air tersebut manusia melakukan berbagai upaya untuk mendapatkannya.Dan dalam usaha pemenuhan kebutuhan air bersih untuk masyarakat ini tidak akan terlepas dari proses penyediaan/produksi air bersih, analisa dari kebutuhan tiap-tiap daerah yang akan disalurkan air bersih hingga 
perhitungan dimensi pipa penyalur serta jaringan pipa distribusi yang menjadi media pendistribusian air bersih ke masyarakat.

Seiring perkembangan zaman yang semakin maju dan semakin bertambahnya jumlah penduduk di dunia secara khususnya di daerah Kota Binjai dan Provinsi Sumatera Utara, maka ketersediaan air bersih merupakan salah satu objek kepentingan yang harus diutamakan. Dalam hal ini Kota Binjai yang merupakan wilayah penunjang ekonomi Provinsi Sumatera Utara membutuhkan pasokan air bersih yang cukup untuk semua masyarakatnya.

Sesuai dengan hal diatas, maka dalam penelitian ini penulis akan membahas dan menganalisa tentang penyediaan air bersih di Kota Binjai hingga tahun 2025 terhitung dari tahun 2018 serta proyeksi pertumbuhan jumlah penduduk dan proyeksi pertambahan jumlah pelanggan air PDAM.

\subsection{Rumusan Masalah}

Topik bahasan atau permasalahan yang akan dibahas dalam laporan penelitian ini adalah sebagai berikut:

1. Berapakah proyeksi pertumbuhan penduduk di Kota Binjai ?

2. Berapakah jumlah kebutuhan air dalam skala debit yang dibutuhkan di Kota Binjai pada tahun 2025 ?

\subsection{Tujuan Penelitian}

Tujuan penulisan laporan penelitian ini adalah sebagai berikut:

1. Mengetahui proyeksi jumlah pertumbuhan jumlah penduduk pada tahun 2018 dan 2025;

2. Mengetahui jumlah kebutuhan air dalam skala debit yang dibutuhkan di Kota Binjai pada tahun 2018 dan 2025.

\subsection{Manfaat Penulisan}

Manfaat yang diharapkan dari penilitian ini adalah sebagai berikut ini.

1. Untuk menambah pengetahuan dalam bidang teknik sumber daya air; 
2. Hasil penulisan ini dapat dijadikan dasar PDAM untuk mengambil kebijakan dalam memenuhi kebutuhan air bersih.

\subsection{Batasan Masalah}

Batasan masalah dari penelitian ini ditentukan sebagai berikut ini.

1. Daerah Penelitian di Kota Binjai sebanyak 5 Kecamatan;

2. Perhitungan proyeksi jumlah penduduk dari tahun 2018 sampai tahun 2025 ;

3. Perhitungan perkiraan jumlah kebutuhan air bersih dari tahun 2018 sampai tahun 2025

\section{TINJAUAN PUSTAKA}

\subsection{Pengertian Air Bersih}

Air Bersih adalah salah satu jenis sumber daya berbasis air yang bermutu baik dan biasa dimanfaatkan oleh manusia untuk dikonsumsi atau dalam melakukan aktivitas mereka sehari-hari dan memenuhi persyaratan untuk pengairan sawah, untuk treatment air minum dan untuk treatment air sanitasi. Persyaratan ditinjau dari persyaratan kandungan kimia, fisik dan biologis. Menurut Permenkes No.492/2010 Air Minum adalah air yang melalui proses pengolahan atau tanpa proses pengolahan yang memenuhi syarat kesehatan yang dapat langsung diminum.

\subsection{Fungsi dan Peranan Air Bagi Makhluk Hidup}

\subsubsection{Manfaat Air bagi Manusia}

Kegunaan air bagi tubuh manusia antara lain adalah untuk membantu proses pencernaan, mengatur metabolisme tubuh, mengangkut zat-zat makanan dalam tubuh, mengatur keseimbangan tubuh dan menjaga tubuh agar tidak kekeringan. Menurut dokter dan para ahli kesehatan, konsumsi air yang dibutuhkan oleh tubuh adalah sebanya 2,5 liter atau setara dengan 8 gelas setiap harinya.

\subsubsection{Manfaat Air bagi Hewan}

Tidak jauh berbeda dengan manusia, hewan juga membutuhkan air sebagai alat bantu untuk proses pencernaan dan juga mengatur suhu tubuh serta menjaga 
metabolisme tubuh hewan. Dan khusus bagi hewan air, air adalah sebagai sarana utama bagi tempat tinggal hewan tersebut. Tanpa adanya air, hewan-hewan yang memiliki habitat air tidak akan mampu bertahan hidup, seperti ikan, mamalia laut dan amfibi..

\subsubsection{Manfaat Air bagi Tumbuhan}

Kelangsungan hidup tumbuhan sangat bergantung pada jumlah air yang tersedia. Kegunaan air bagi tumbuhan antara lain untuk menjaga proses pertumbuhan serta menjaga agar tumbuhan tidak mengalami kekeringan. Dan apabila tumbuhan kekurangan suplai air, maka tumbuhan akan mengalami kekeringan yang mengakibatkan tumbuhan tersebut akan mati.

\subsection{Sumber Air Bersih}

Ada berbagai macam sumber air yang dapat dimanfaatkan sebagai sumber air bersih, yakni diantaranya ialah:

1. Air Atmosfir

2. Air Permukaan

3. Air Tanah

4. Mata Air

Tabel 1. Kelebihan dan Kekurangan Masing-Masing Sumber Air

\begin{tabular}{|c|c|c|}
\hline Sumber Air & Kelebihan & Kekurangan \\
\hline Air Permukaan & $\begin{array}{l}\text { 1. Memungkinkan untuk } \\
\text { digunakan sebagai sumber air } \\
\text { baku untuk sistem penyediaan } \\
\text { air bersih yang relatif besar } \\
\text { ditinjau dari kuantitas dan } \\
\text { kualitas serta kontinuitas yang } \\
\text { dapat dipenuhi. } \\
\text { 2. Lokasi sumber yang mudah } \\
\text { diketahui dan dijangkau. } \\
\text { 3. Data mengenai sumber air } \\
\text { relatif mudah didapat. } \\
\end{array}$ & $\begin{array}{l}\text { 1. Untuk memperbaiki kualitas } \\
\text { air diperlukan pengolahan } \\
\text { yang lengkap. } \\
\text { 2. Memerlukan pompa untuk } \\
\text { menaikkan air baku karena } \\
\text { permukaan yang biasanya } \\
\text { terletak pada daerah yang } \\
\text { relatif rendah. } \\
\text { 3. Cukup sulit dan rumit untuk } \\
\text { melindungi sumber air dari } \\
\text { kontaminasi. }\end{array}$ \\
\hline Air Tanah & $\begin{array}{l}\text { 1. Air tanah (dalam) pada } \\
\text { umumnya cukup jernih dan } \\
\text { tidak memerlukan pengolahan } \\
\text { yang ketat dan lengkap. } \\
\text { 2. Kualitas air (dalam) pada } \\
\text { umumnya cukup stabil } \\
\text { sepanjang waktu. } \\
\text { 3. Mudah untuk melindungi } \\
\text { sumber air dari kontaminasi. }\end{array}$ & $\begin{array}{l}\text { 1. Kuantitas terbatas, kadang- } \\
\text { kadang dipengaruhi oleh } \\
\text { musim. } \\
\text { 2. Di daerah tertentu masih } \\
\text { terdapat masalah kualitas air } \\
\text { seperti kandungan bahan } \\
\text { kimia yang cukup tinggi. }\end{array}$ \\
\hline Mata Air & 1. Kualitas air relatif baik. & 1. Lokasi mata air yang sulit \\
\hline
\end{tabular}




\begin{tabular}{|l|l|l|}
\hline & $\begin{array}{l}\text { 2. Tidak memerlukan pengolahan } \\
\text { lengkap. }\end{array}$ & dijangkau \\
& $\begin{array}{l}\text { 3. Fluktuasi debit yang konstan. } \\
\text { 4. Tidak memerlukan sistem } \\
\text { pemompaan untuk } \\
\text { pengambilan air }\end{array}$ & \\
\hline
\end{tabular}

\subsection{Persyaratan dalam Penyediaan Air Bersih}

Sistem penyedian air bersih harus memenuhi beberapa persyaratan utama. Persyaratan-persyaratan tersebut meliputi persyaratan kualitatif, persyaratan kuantitatif dan persyaratan kontinuitas serta persyaratan tekanan air.

1. Persyaratan Kualitatif

Persyaratan kualitatif adalah persyaratan yang menggambarkan mutu atau kualitas air bersih. Persyaratan kualitatif ini meliputi persyaratan fisik, persyaratan kimia, persyaratan biologis dan persyaratan radiologis.

a. Syarat fisik

Syarat fisik yang harus dimiliki oleh air bersih yaitu:

1. Air tidak boleh berwarna;

2. Air tidak boleh berasa;

3. Air tidak boleh berbau;

4. Suhu air hendaknya dibawah udara $\left(\operatorname{sejuk} \pm 25^{\circ} \mathrm{C}\right)$;

5. Air harus jernih.

Syarat-syarat kekeruhan dan warna harus dipenuhi oleh setiap jenis air minum di mana dilakukan penyaringan dalam pengolahannya (Sutrisno, T, dkk, 2010: 21).

b. Syarat kimia

Syarat kimia air bersih adalah syarat yang membatasi air bersih dari kandungan jumlah zat kimia di dalamnya. Air bersih yang layak tidak boleh mengandung bahan-bahan kimia dalam jumlah yang melampaui batas. Beberapa kandungan zat kimia yang selalu teradapat dalam air antara lain adalah $\mathrm{pH}$, total solid, zat organik, $\mathrm{CO}_{2}$ agresif, kesadahan, Kalsium (Ca), Besi $(\mathrm{Fe})$, Mangan $(\mathrm{Mn})$, Tembaga $(\mathrm{Cu})$, Seng $(\mathrm{Zn})$, Chlorida $(\mathrm{Cl})$, Nitrit $\left(\mathrm{NO}_{2}\right)$, Flourida $(\mathrm{F})$, serta logam berat.

2. Persyaratan Kuantitatif 
Persyaratan kuantitatif dalam penyediaan air bersih adalah ditinjau dari banyaknya air baku yang tersedia. Artinya, air tersebut bernilai guna demi pemenuhan pemakainya. Dalam hal ini, jumlah air yang dibutuhkan sanagt tergantung pada tingkat kemajuan teknologi dan social ekonomi masyarakat setempat. Sebagai contoh Negara negara yang telah maju memerlukan air bersih yang lebih banyak dibandingkan dengan masyarakat di Negara Negara berkembang.

3. Persyaratan Kontinuitas

Persyaratan kontinuitas ini sangat erat hubungannya dengan kuantitas air yang tersedia yaitu air baku yang ada di alam. Arti kontinuitas disini adalah bahwa air baku untuk air bersih tersebut dapat diambil terus menerus dengan fluktuasi debit yang relative tetap, baik pada saat musim kemarau maupun musim hujan.

4. Persyaratan Tekanan air

Tekanan air yang kurang mencukupi akan menimbulkan kesulitan dalam pemakaian air. Tekanan yang berlebihan dapat menimbulkan rasa sakit terkena pancaran air serta mempercepat kerusakan peralatan plambing, dan menambah kemungkinan timbulnya pukulan air. Tekanan air yang berada pada sistem plambing (pada pipa) tekanannya harus sesuai dengan ketentuan yang berlaku, diantaranya yaitu, untuk perumahan dan hotel antara $2,5 \mathrm{~kg} / \mathrm{cm} 2$ atau 25 meter kolom air (mka) sampai 3,5 kg/cm2 atau 35 meter kolom air (mka). Tekanan tersebut tergantung dari peraturan setempat. (SNI 03-6481-2000)

\subsection{Proyeksi Jumlah Penduduk}

Menurut Anonimus, (1990), dalam Standar Kriteria Desain Sistem Penyediaan Air Bersih, proyeksi jumlah penduduk di masa yang akan datang dapat diprediksikan berdasarkan laju pertumbuhan penduduk yang direncanakan.

\section{Metode Aritmatika}

Proyeksi penduduk dengan metode aritmatika mengasumsikan bahwa jumlah penduduk pada masa yang akan datang akan bertambah dengan jumlah yang sama setiap tahun. Hasil proyeksi akan berbentuk suatu garis lurus.

Formula yang digunakan pada metode proyeksi aritmatika adalah

$$
P_{n}=P_{0} \times(1+n \times r)
$$

Received May01 ${ }^{\text {st }}, 2020$; Revised June 08 ${ }^{\text {th }}, 2020$; Accepted June $10^{\text {th }}, 2020$ 
dimana angka pertumbuhan penduduk $r=\frac{\left(\frac{P_{n}}{P_{0}}\right)-1}{t}$ dengan :

Pn adalah jumlah penduduk pada tahun $n$

P0 adalah jumlah penduduk pada tahun dasar

$\mathrm{r}$ adalah angka pertumbuhan penduduk

t adalah selisih antara tahun dasar dengan tahun $\mathrm{n}$

2. Metode Geometrik

Proyeksi penduduk dengan metode geometri menggunakan asumsi bahwa jumlah penduduk akan bertambah secara geometri dengan menggunakan dasar perhitungan majemuk (Adioetomo dan Samosir, 2010). Laju pertumbuhan penduduk (rate of growth) dianggap sama untuk setiap tahun.

Formula yang digunakan pada metode geometri adalah:

$$
P_{n}=P_{0} \times(1+r)^{n}
$$

dimana angka pertumbuhan penduduk $r=\frac{\left(\frac{P_{n}}{P_{0}}\right)^{1 / t}}{t}-1$

3. Metode Eksponensial

Metode eksponensial menggambarkan pertambahan penduduk yang terjadi secara sedikit-sedikit sepanjang tahun, berbeda dengan metode geometri yang mengasumsikan bahwa pertambahan penduduk hanya terjadi pada satu saat selama kurun waktu tertentu (Adioetomo dan Samosir 2010).

Formula yang digunakan pada metode eksponensial adalah:

$$
P_{n}=P_{0} \times e^{(n \times r)}
$$

dimana angka pertumbuhan penduduk $r=\frac{\left\{\ln \left(\frac{P_{n}}{P_{0}}\right)\right\}}{t}$

Keterangan: $\mathrm{Pn} \quad=$ Jumlah penduduk pada tahun $\mathrm{n}$ (jiwa)

Po = Jumlah penduduk pada tahun awal (jiwa)

$\mathrm{n} \quad=$ Periode waktu dalam tahun

Received May01 ${ }^{\text {st }}$,2020; Revised June 08 ${ }^{\text {th }}$, 2020; Accepted June 10 ${ }^{\text {th }}$, 2020 


$$
\mathrm{r} \quad=\text { Laju pertumbuhan penduduk }(\%)
$$

\subsection{Kebutuhan Air Bersih}

Kebutuhan air bersih adalah banyaknya air yang diperlukan untuk melayani kebutuhan penduduk pada suatu wilayah tertentu. Kebutuhan air masyarakat dibagi dua klasifikasi pemakaian air, yaitu untuk kebutuhan domestik (rumah tangga) dan kebutuhan non-domestik. Untuk memproyeksi jumlah kebutuhan air bersih dapat dilakukan berdasarkan perkiraan kebutuhan air untuk berbagai macam tujuan ditambah perkiraan kehilangan air.

\subsubsection{Kebutuhan Air Bersih Domestik}

Menurut Anonimus (1990), kebutuhan domestik adalah kebutuhan yang bertujuan untuk memenuhi kebutuhan air bersih bagi keperluan rumah tangga melalui sambungan rumah (SR) dan kebutuhan umum yang disediakan melalui fasilitas hidran umum (HU). Ada dua faktor perlu diperhatikan untuk memenuhi kebutuhan air domestik masyarakat, yaitu:

a. Jumlah penduduk yang akan dilayani menurut target tahapan perencanaan sesuai dengan rencana cakupan pelayanan;

b. Tingkat pemakaian air bersih diasumsikan tergantung pada kategori daerah dan jumlah penduduknya.

Kebutuhan air bersih penduduk juga dibagi berdasarkan jenis kota dan jumlah penduduk di suatu wilayah tertentu seperti yang tertera pada Tabel 2.2 berikut.

Tabel 2. Kebutuhan Air Bersih Berdasarkan Jenis Kota dan Jumlah

\begin{tabular}{|c|c|c|c|}
\hline No. & Kategori & $\begin{array}{c}\text { Jumlah Penduduk } \\
\text { (jiwa) }\end{array}$ & $\begin{array}{c}\text { Pemakaian Air } \\
\text { (liter/hari/jiwa) }\end{array}$ \\
\hline 1. & Metropolitan & $>1.000 .000$ & 150 \\
\hline 2. & Kota Besar & $500.000-1.000 .000$ & 120 \\
\hline 3. & Kota Kecil & $100.000-500.000$ & 100 \\
\hline 4. & Kota Sedang & $25.000-100.000$ & 90 \\
\hline 5. & Ibukota Kecamatan & $10.000-25.000$ & 60 \\
\hline 6. & Pedesaan & $<10.000$ & 50 \\
\hline
\end{tabular}

Sumber: Cipta Karya, 1998.

\subsubsection{Fluktuasi Kebutuhan Air}

Kebutuhan air pada suatu daerah tidak selalu sama untuk setiap saat dan setiap harinya. Kebutuhan air tersebut akan mengalami fluktuasi sesuai dengan aktivitas 
penggunaan air selama proses pemakainnya dan juga tergantung pada keseharian masyarakat pengguna air. Kebutuhan air itu sendiri terbagi ke dalam tiga kelompok kebutuhan, yaitu:

1. Kebutuhan rata-rata (Qr);

2. Kebutuhan harian maksimum $(\mathrm{Qm})$;

3. Kebutuhan pada jam puncak.

Kebutuhan air harian maksimum dan kebutuhan pada jam puncak pemakaian dapat dihitung berdasarkan kebutuhan dasar dan nilai kebocoran dengan cara sebagai berikut:

a. Kebutuhan harian maksimum $=(1,2-1,5) \times$ kebutuhan air rata-rata;

b. Kebutuhan pada jam puncak $=(1,5-2) \mathrm{x}$ kebutuhan harian maksimum.

\subsection{Menara Air/Reservoir}

Kapasitas Reservoir IPA Marcapada adalah 175 1/dtk atau mampu menghasilkan sebesar $15.120 \mathrm{~m}^{3} /$ hari. Sementara itu kapasitas reservoir eksisting hanya $2000 \mathrm{~m}^{3}$. Oleh karena itu saat ini kapasitas reservoir eksisting hanya mampu untuk melayani kurang lebih 3 jam pelayanan air saja. Dengan demikian rencana penambahan kapasitas reservoir/ menara air yang diperlukan adalah seperti yang direncanakan pada tabel berikut.

Tabel 3. Pembangunan Reservoir Kota Binjai

\begin{tabular}{|l|c|c|l|c|}
\hline $\begin{array}{c}\text { Nama } \\
\text { Pembangunan } \\
\text { Reservoir }\end{array}$ & $\begin{array}{c}\text { Kapasitas } \\
\text { (m3) }\end{array}$ & $\begin{array}{c}\text { Jam } \\
\text { Pelayanan } \\
\text { Puncak }\end{array}$ & Tipe Reservoir & $\begin{array}{c}\text { Rencana Tahun } \\
\text { Pembangunan }\end{array}$ \\
\hline $\begin{array}{l}\text { Reservoir } \\
\text { Kebun Lada II }\end{array}$ & 3800 & 3,5 jam & $\begin{array}{l}\text { Reservoir Produksi } \\
\text { langsung sebagai } \\
\text { booster pump }\end{array}$ & 2023 \\
\hline $\begin{array}{l}\text { Reservoir } \\
\text { Marcapada II }\end{array}$ & 2500 & 3,5 jam & $\begin{array}{l}\text { Reservoir Produksi } \\
\text { langsung sebagai } \\
\text { booster pump }\end{array}$ & 2032 \\
\hline
\end{tabular}

Sumber: RISPAM Kota Binjai 


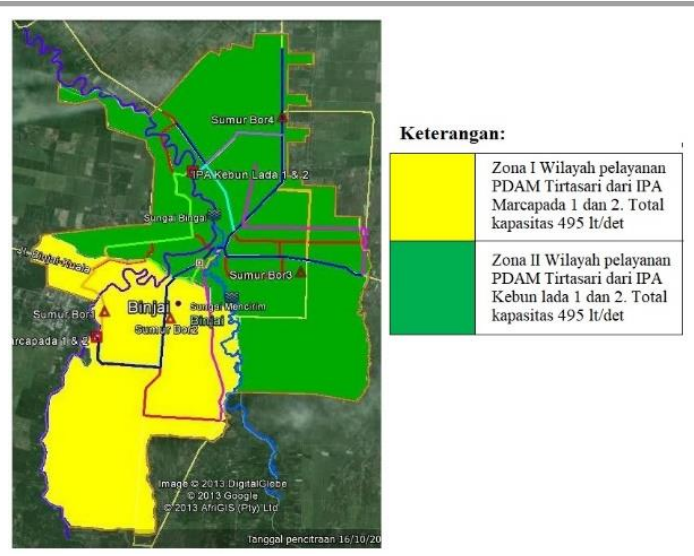

\section{Gambar 1. Lokasi Reservoir dan Pembagian Zona Wilayah Pelayanan}

\section{METODE PENELITIAN}

\subsection{Lokasi Penelitian}

Penelitian ini berolakasi di Kota Binjai dimana wilayah yang ditinjau adalah 5 kecamatan yaitu: Binjai Barat, Binjai Kota, Binjai Selatan, Binjai Timur, dan Binjai Utara.

\subsection{Persiapan}

Tahap persiapan merupakan rangkaian kegiatan sebelum pengumpulan dan pengolahan data. Pada tahap ini disusun kegiatan yang harus dilakukan dengan tujuan untuk mengefektifkan waktu, tenaga dan materi dalam pelaksanaannya. Sehingga dalam proses penelitian ini perlu dibuat suatu pedoman kerja yang matang, supaya tercapainya sasaran yang diharapkan sesuai dengan bobot persoalan yang diangkat.

\subsection{Tahapan Perencanaan}

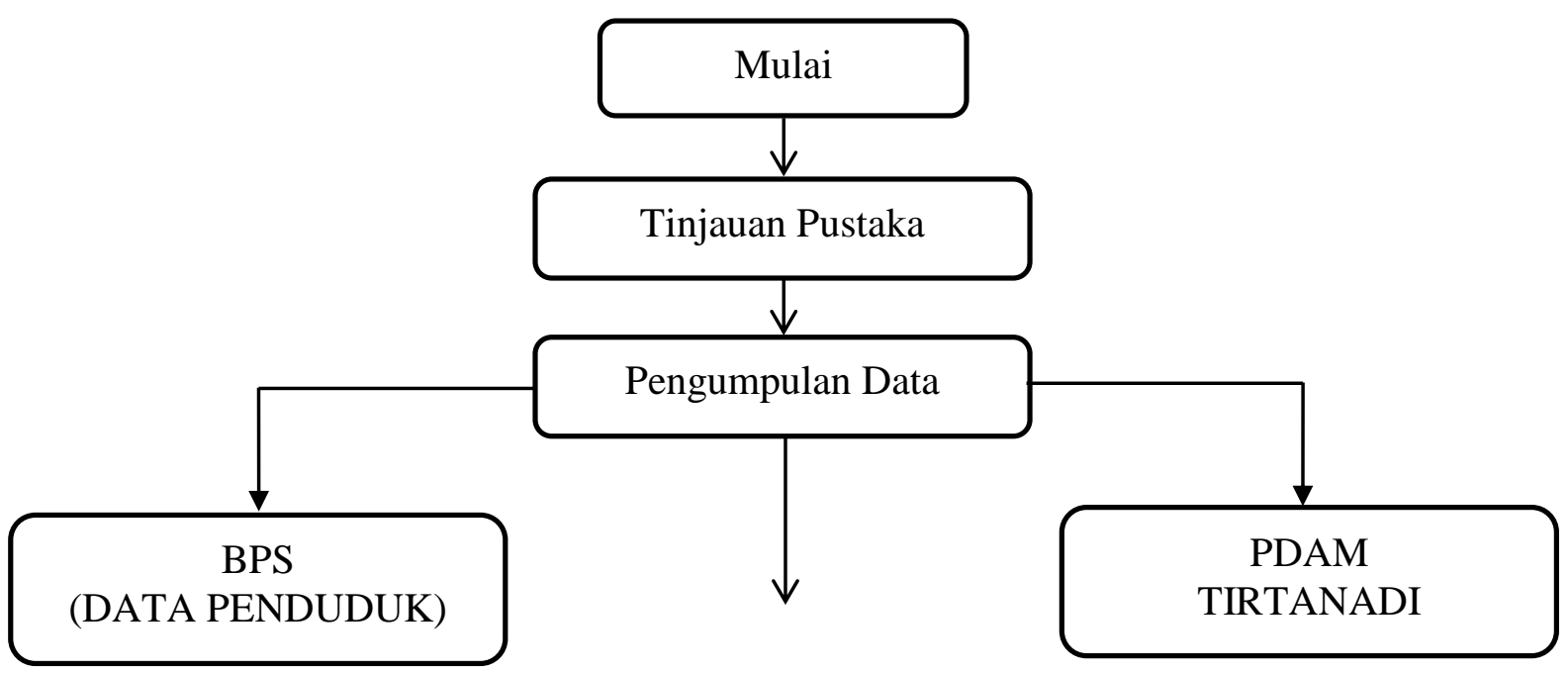

Received May01 ${ }^{\text {st }}$,2020; Revised June 08 ${ }^{\text {th }}, 2020$; Accepted June 10 ${ }^{\text {th }}, 2020$ 


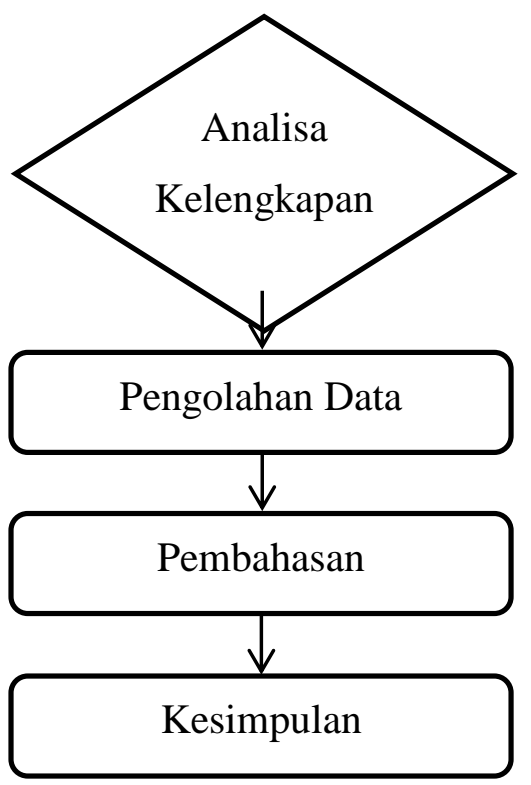

\section{Gambar 2. Diagram Alir Pelaksanaan Penelitian}

\subsection{Pengumpulan Data}

Adapun data yang akan dikumpulkan pada penelitian ini yaitu:

1. Data Sekunder

Yaitu data yang diperoleh dari instansi terkait. Data sekunder dalam hal ini ialah Data Penduduk dan Data pengguna Air PDAM yang diperoleh dari Badan Pusat Statistik Sumatera Utara. Data tersebut digunakan untuk mengetahui proses pertumbuhan penduduk, data domestik, dan data nondomestik

2. Data Tersier

Data tersier yang diperlukan dalam hal ini ialah data geografis wilayah kota binjai seperti pada table berikut.

Tabel 4. Letak dan Geografis Kota Binjai, 2016

\begin{tabular}{|l|c|}
\hline Letak Astronomis & $3^{\circ} 31^{\prime} 40^{\prime \prime}-3^{\circ} 40^{\prime} 2^{\prime \prime}$ Lintang Utara \\
\hline & $98^{\circ} 27^{\prime} 3^{\prime \prime}-98^{\circ} 32^{\prime} 32^{\prime \prime}$ Bujur \\
Timur
\end{tabular}




\begin{tabular}{|l|l|}
\hline \multicolumn{2}{|c|}{ Batas-batas/ Boundaries } \\
\hline \multirow{2}{*}{ Utara/North } & $\begin{array}{l}\text { Kecamatan Binjai Kabupaten } \\
\text { Langkat dan Kecamatan Hamparan } \\
\text { Perak Kabupaten Deli Serdang }\end{array}$ \\
\hline Timur/East & $\begin{array}{l}\text { Kecamatan Sunggal Kabupaten Deli } \\
\text { Serdang }\end{array}$ \\
\hline \multirow{2}{*}{ Barat/West } & Kecamatan Selesai Kabupaten \\
& Langkat \\
\hline
\end{tabular}

Sumber: Dinas Ketahanan Pangan dan Pertanian Kota Binjai.

\section{ANALISA DAN HASIL}

\subsection{Data Exisiting}

Tabel 5. Sumber Air Baku dan Unit Produksi PDAM Tirtasari Binjai

\begin{tabular}{|c|c|c|c|c|}
\hline \multirow{2}{*}{ No. } & \multirow{2}{*}{ Nama } & \multicolumn{2}{|c|}{ Kapasitas (1/det) } & \multirow{2}{*}{ Sumber Air } \\
\hline & & Terpasang & Produksi & \\
\hline 1. & IPA Marcapada & 150 & 150 & Sungai Bingai \\
\hline 2. & Sumur Bor Berngam & 10 & - & Air Tanah Dalam \\
\hline 3. & Sumur Bor Tandam & 10 & - & Air Tanah Dalam \\
\hline 4. & Sumur Bor Mencirim & 25 & 5 & Air Tanah Dalam \\
\hline & Total & 195 & 155 & \\
\hline
\end{tabular}

Sumber : BPKB, Audit Kinerja PDAM Tirtasari 2010.

\subsection{Analisa Kebutuhan Air}

\subsubsection{Kecamatan Binjai Barat}

1. Analisis Proyeksi Pertumbuhan Penduduk

Tabel 6. Proyeksi Jumlah Penduduk Kecamatan Binjai Barat Tahun s/d 2025

\begin{tabular}{|c|c|c|c|c|c|}
\hline No. & Tahun & $\mathbf{N}$ & $\begin{array}{c}\text { Metode Geometrik } \\
P_{n}= \\
49926(1+0,0306)^{\wedge} n \\
(\text { jiwa })\end{array}$ & $\begin{array}{c}\text { Metode Aritmatik } \\
P_{n}=49926+806 n \\
\text { (jiwa) }\end{array}$ & Rata- rata \\
\hline 1. & 2018 & 0 & 49926 & 49926 & 49926 \\
\hline 2. & 2019 & 1 & 51454 & 50732 & 51093 \\
\hline 3. & 2020 & 2 & 53028 & 51538 & 52283 \\
\hline 4. & 2021 & 3 & 54651 & 52344 & 53497 \\
\hline 5. & 2022 & 4 & 56323 & 53150 & 54737 \\
\hline
\end{tabular}




\begin{tabular}{|l|l|l|l|l|l|}
\hline 6. & 2023 & 5 & 58047 & 53956 & 56001 \\
\hline 7. & 2024 & 6 & 59823 & 54762 & 57292 \\
\hline 8. & 2025 & 7 & 61654 & 55568 & 58611 \\
\hline
\end{tabular}

2. Analisis Proyeksi Kebutuhan Air

Tabel 7. Proyeksi Jumlah Kebutuhan Air Domestik dan Non-Domestik

Kecamatan Binjai Barat Tahun s/d 2025.

\begin{tabular}{|c|c|c|c|c|c|}
\hline No. & Tahun & $\begin{array}{c}\text { Jumlah } \\
\text { Penduduk }\end{array}$ & $\begin{array}{c}\text { Konsumsi Air } \\
\text { Rata-Rata }\end{array}$ & $\begin{array}{c}\text { Kebutuhan Air } \\
\text { Domestik }\end{array}$ & $\begin{array}{c}\text { Kebutuhan } \\
\text { Air Non } \\
\text { Domestik } \\
\text { (liwa) }\end{array}$ \\
\hline \hline 1 & 2018 & 49926 & 100 & 57,785 & 11,557 \\
\hline 2 & 2019 & 51093 & 100 & 59,135 & 11,827 \\
\hline 3 & 2020 & 52283 & 100 & 60,513 & 12,103 \\
\hline 4 & 2021 & 53497 & 100 & 61,918 & 12,384 \\
\hline 5 & 2022 & 54737 & 100 & 63,353 & 12,671 \\
\hline 6 & 2023 & 56001 & 100 & 64,816 & 12,963 \\
\hline 7 & 2024 & 57292 & 100 & 66,310 & 13,262 \\
\hline 8 & 2025 & 58611 & 100 & 67,837 & 13,567 \\
\hline
\end{tabular}

\subsubsection{Kecamatan Binjai Kota}

1. Analisis Proyeksi Pertumbuhan Penduduk

Tabel 8. Proyeksi Jumlah Penduduk Kecamatan Binjai Kota Tahun s/d 2025

\begin{tabular}{|c|c|c|c|c|c|}
\hline No. & Tahun & $\mathrm{N}$ & $\begin{array}{c}\text { Metode Geometrik } \\
\mathrm{P}_{\mathrm{n}}=49926(1+0,0306)^{\wedge} \mathrm{n} \\
\text { (jiwa) }\end{array}$ & $\begin{array}{l}\text { Metode Aritmatik } \\
P_{n}=49926+806 n \\
\text { (jiwa) }\end{array}$ & Rata- rata \\
\hline 1. & 2018 & 0 & 28302 & 28302 & 28302 \\
\hline 2. & 2019 & 1 & 28585 & 28141 & 28363 \\
\hline 3. & 2020 & 2 & 28871 & 27980 & 28425 \\
\hline 4. & 2021 & 3 & 29160 & 27819 & 28489 \\
\hline 5. & 2022 & 4 & 29451 & 27658 & 28555 \\
\hline 6. & 2023 & 5 & 29746 & 27497 & 28621 \\
\hline 7. & 2024 & 6 & 30043 & 27336 & 28690 \\
\hline 8. & 2025 & 7 & 30344 & 27175 & 28759 \\
\hline
\end{tabular}

2. Analisis Proyeksi Kebutuhan Air 
Tabel 9. Proyeksi Jumlah Kebutuhan Air Domestik dan Non-Domestik Kecamatan Binjai Kota Tahun s/d 2025.

\begin{tabular}{|c|c|c|c|c|c|}
\hline No. & Tahun & $\begin{array}{c}\text { Jumlah } \\
\text { Penduduk }\end{array}$ & $\begin{array}{c}\text { Konsumsi Air } \\
\text { Rata-Rata } \\
\text { (lt/jiwa/hari) }\end{array}$ & $\begin{array}{c}\text { Kebutuhan Air } \\
\text { Domestik } \\
\text { (lt/dtk) }\end{array}$ & $\begin{array}{c}\text { Kebutuhan } \\
\text { Air Non } \\
\text { Domestik } \\
\text { (lt/dtk) }\end{array}$ \\
\hline \hline 1 & 2018 & 28302 & 100 & 32,757 & 6,551 \\
\hline 2 & 2019 & 28363 & 100 & 32,828 & 6,566 \\
\hline 3 & 2020 & 28425 & 100 & 32,899 & 6,580 \\
\hline 4 & 2021 & 28489 & 100 & 32,973 & 6,595 \\
\hline 5 & 2022 & 28555 & 100 & 33,050 & 6,610 \\
\hline 6 & 2023 & 28621 & 100 & 33,126 & 6,625 \\
\hline 7 & 2024 & 28690 & 100 & 33,206 & 6,641 \\
\hline 8 & 2025 & 28759 & 100 & 33,286 & 6,657 \\
\hline
\end{tabular}

\subsubsection{Kecamatan Binjai Selatan}

1. Analisis Proyeksi Pertumbuhan Penduduk

Tabel 10. Proyeksi Jumlah Penduduk Kecamatan Binjai Selatan Tahun s/d 2025

\begin{tabular}{|c|c|c|c|c|c|}
\hline No. & Tahun & $\mathbf{N}$ & $\begin{array}{c}\text { Metode Geometrik } \\
\left.\mathbf{P}_{\mathbf{n}}=\mathbf{4 9 9 2 6 ( 1 + 0 , 0 3 0 6}\right)^{\wedge} \mathbf{n} \\
\text { (jiwa) }\end{array}$ & $\begin{array}{c}\text { Metode Aritmatik } \\
\mathbf{P}_{\mathbf{n}}=\mathbf{4 9 9 2 6 + 8 0 6} \mathbf{n} \\
\text { (jiwa) }\end{array}$ & Rata- rata \\
\hline 1. & 2018 & 0 & 56602 & 56602 & 56602 \\
\hline 2. & 2019 & 1 & 57655 & 57178 & 57416 \\
\hline 3. & 2020 & 2 & 58727 & 57754 & 58241 \\
\hline 4. & 2021 & 3 & 59820 & 58330 & 59075 \\
\hline 5. & 2022 & 4 & 60932 & 58906 & 59919 \\
\hline 6. & 2023 & 5 & 62065 & 59482 & 60774 \\
\hline 7. & 2024 & 6 & 63220 & 60058 & 61639 \\
\hline 8. & 2025 & 7 & 64396 & 60634 & 62515 \\
\hline
\end{tabular}

2. Analisis Proyeksi Kebutuhan Air

Tabel 11. Proyeksi Jumlah Kebutuhan Air Domestik dan Non-Domestik

Kecamatan Binjai Selatan Tahun s/d 2025.

\begin{tabular}{|c|c|c|c|c|c|}
\hline No. & Tahun & $\begin{array}{c}\text { Jumlah } \\
\text { Penduduk } \\
\text { (jiwa) }\end{array}$ & $\begin{array}{l}\text { Konsumsi Air } \\
\text { Rata-Rata } \\
\text { (lt/jiwa/hari) }\end{array}$ & $\begin{array}{c}\text { Kebutuhan Air } \\
\text { Domestik } \\
(1 \mathrm{t} / \mathrm{dtk})\end{array}$ & $\begin{array}{c}\text { Kebutuhan } \\
\text { Air Non } \\
\text { Domestik } \\
\text { (lt/dtk) }\end{array}$ \\
\hline 1 & 2018 & 56602 & 100 & 65,512 & 13,102 \\
\hline
\end{tabular}




\begin{tabular}{|l|l|l|l|l|l|}
2 & 2019 & 57416 & 100 & 66,454 & 13,291 \\
\hline 3 & 2020 & 58241 & 100 & 67,409 & 13,482 \\
\hline 4 & 2021 & 59075 & 100 & 68,374 & 13,675 \\
\hline 5 & 2022 & 59919 & 100 & 69,351 & 13,870 \\
\hline 6 & 2023 & 60774 & 100 & 70,340 & 14,068 \\
\hline 7 & 2024 & 61639 & 100 & 71,341 & 14,268 \\
\hline 8 & 2025 & 62515 & 100 & 72,355 & 14,471 \\
\hline
\end{tabular}

\subsubsection{Kecamatan Binjai Timur}

1. Analisis Proyeksi Pertumbuhan Penduduk

Tabel 12. Proyeksi Jumlah Penduduk Kecamatan Binjai Timur Tahun s/d 2025

\begin{tabular}{|c|c|c|c|c|c|}
\hline No. & Tahun & $\mathbf{N}$ & $\begin{array}{c}\text { Metode Geometrik } \\
\left.\mathbf{P}_{\mathbf{n}}=\mathbf{4 9 9 2 6 ( 1 + 0 , 0 3 0 6}\right)^{\wedge} \mathbf{n} \\
(\text { jiwa) }\end{array}$ & $\begin{array}{c}\text { Metode Aritmatik } \\
\mathbf{P}_{\mathbf{n}}=\mathbf{4 9 9 2 6}+\mathbf{8 0 6} \mathbf{n} \\
(\text { jiwa) }\end{array}$ & Rata- rata \\
\hline 1. & 2018 & 0 & 60631 & 60631 & 60631 \\
\hline 2. & 2019 & 1 & 62874 & 61782 & 62328 \\
\hline 3. & 2020 & 2 & 65201 & 62933 & 64067 \\
\hline 4. & 2021 & 3 & 67613 & 64084 & 65849 \\
\hline 5. & 2022 & 4 & 70115 & 65235 & 67675 \\
\hline 6. & 2023 & 5 & 72709 & 66386 & 71468 \\
\hline 7. & 2024 & 6 & 75399 & 67537 & 73439 \\
\hline 8. & 2025 & 7 & 78189 & 68688 & \\
\hline
\end{tabular}

2. Analisis Proyeksi Kebutuhan Air

Tabel 13. Proyeksi Jumlah Kebutuhan Air Domestik dan Non-Domestik

Kecamatan Binjai Timur Tahun s/d 2025.

\begin{tabular}{|c|c|c|c|c|c|}
\hline No. & Tahun & $\begin{array}{c}\text { Jumlah } \\
\text { Penduduk } \\
\text { (jiwa) }\end{array}$ & $\begin{array}{c}\text { Konsumsi Air } \\
\text { Rata-Rata } \\
\text { (lt/jiwa/hari) }\end{array}$ & $\begin{array}{c}\text { Kebutuhan Air } \\
\text { Domestik } \\
\text { (lt/dtk) }\end{array}$ & $\begin{array}{c}\text { Kebutuhan } \\
\text { Air Non } \\
\text { Domestik } \\
\text { (lt/dtk) }\end{array}$ \\
\hline \hline 1 & 2018 & 60631 & 100 & 70,175 & 14,035 \\
\hline 2 & 2019 & 62328 & 100 & 72,139 & 14,428 \\
\hline 3 & 2020 & 64067 & 100 & 74,152 & 14,830 \\
\hline 4 & 2021 & 65849 & 100 & 76,214 & 15,243 \\
\hline 5 & 2022 & 67675 & 100 & 78,328 & 15,666 \\
\hline 6 & 2023 & 69548 & 100 & 80,495 & 16,099 \\
\hline 7 & 2024 & 71468 & 100 & 82,718 & 16,544 \\
\hline 8 & 2025 & 73439 & 100 & 84,999 & 17,000 \\
\hline
\end{tabular}




\subsubsection{Kecamatan Binjai Utara}

1. Analisis Proyeksi Pertumbuhan Penduduk

Tabel 14. Proyeksi Jumlah Penduduk Kecamatan Binjai Utara Tahun s/d 2025

\begin{tabular}{|c|c|c|c|c|c|}
\hline No. & Tahun & $\mathbf{N}$ & $\begin{array}{c}\text { Metode Geometrik } \\
\left.\mathbf{P}_{\mathbf{n}}=\mathbf{4 9 9 2 6 ( 1 + 0 , 0 3 0 6}\right)^{\wedge} \mathbf{n} \\
\text { (jiwa) }\end{array}$ & $\begin{array}{c}\text { Metode Aritmatik } \\
\mathbf{P}_{\mathbf{n}}=\mathbf{4 9 9 2 6 + 8 0 6} \mathbf{n} \\
\text { (jiwa) }\end{array}$ & Rata- rata \\
\hline 1. & 2018 & 0 & 78831 & 78831 & 78831 \\
\hline 2. & 2019 & 1 & 79801 & 79370 & 79585 \\
\hline 3. & 2020 & 2 & 80782 & 79909 & 80346 \\
\hline 4. & 2021 & 3 & 81776 & 80448 & 81112 \\
\hline 5. & 2022 & 4 & 82782 & 81526 & 82663 \\
\hline 6. & 2023 & 5 & 83800 & 82065 & 83448 \\
\hline 7. & 2024 & 6 & 84831 & 82604 & 84239 \\
\hline 8. & 2025 & 7 & 85874 & & \\
\hline
\end{tabular}

2. Analisis Proyeksi Kebutuhan Air

Tabel 15. Proyeksi Jumlah Kebutuhan Air Domestik dan Non-Domestik Kecamatan Binjai Utara Tahun s/d 2025.

\begin{tabular}{|c|c|c|c|c|c|}
\hline No. & Tahun & $\begin{array}{c}\text { Jumlah } \\
\text { Penduduk }\end{array}$ & $\begin{array}{c}\text { Konsumsi Air } \\
\text { Rata-Rata }\end{array}$ & $\begin{array}{c}\text { Kebutuhan Air } \\
\text { Domestik }\end{array}$ & $\begin{array}{c}\text { Kebutuhan } \\
\text { Air Non } \\
\text { Domestik }\end{array}$ \\
\hline \hline 1 & 2018 & 78831 & 100 & 91,240 & 18,248 \\
\hline 2 & 2019 & 79585 & 100 & 92,112 & 18,422 \\
\hline 3 & 2020 & 80346 & 100 & 92,993 & 18,599 \\
\hline 4 & 2021 & 81112 & 100 & 93,880 & 18,776 \\
\hline 5 & 2022 & 81884 & 100 & 94,773 & 18,955 \\
\hline 6 & 2023 & 82663 & 100 & 95,675 & 19,135 \\
\hline 7 & 2024 & 83448 & 100 & 96,583 & 19,317 \\
\hline 8 & 2025 & 84239 & 100 & 97,499 & 19,500 \\
\hline
\end{tabular}




\subsection{Total Kebutuhan Air Rata-rata dan Proyeksi Jumlah Penduduk di Kota Binjai}

Total kebutuhan air pada Kota Binjai adalah seluruh jumlah kebutuhan pada kecamatan tersebut. Pada Tabel dibawah ini berikut dapat dilihat berapa besar total

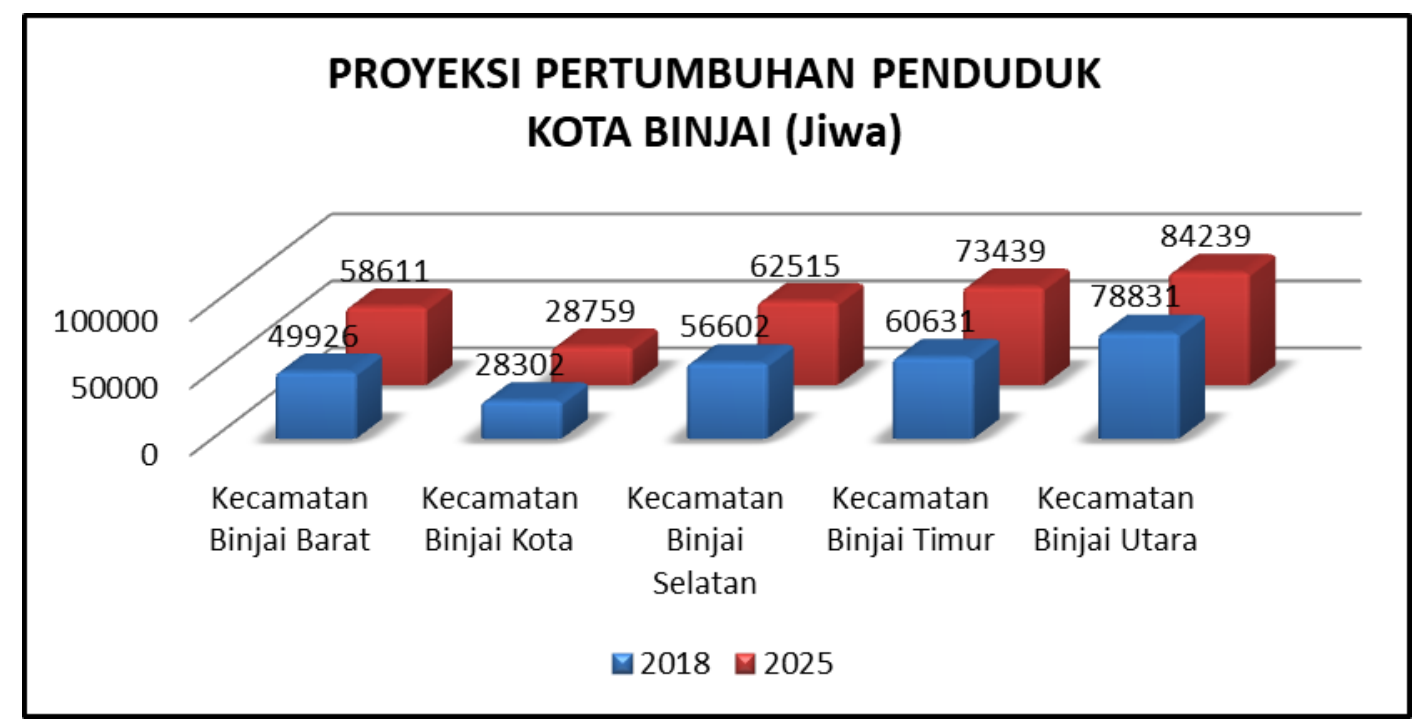

kebutuhan air dalam sehari di tiap Kecamatan yang ada di Kota Binjai pada tahun 2025.

Gambar 3. Proyeksi Pertumbuhan Penduduk pada Kota Binjai Tahun 2018 dan 2025

Tabel 16. Proyeksi Kebutuhan Air Rata - Rata Pada Kota Binjai Tahun 2025

\begin{tabular}{|c|c|c|c|c|c|}
\hline $\mathbf{2 0 2 5}$ & $\begin{array}{c}\text { Kebutuhan } \\
\text { Domestik }\end{array}$ & $\begin{array}{c}\text { Kebutuhan } \\
\text { Non } \\
\text { Domestik }\end{array}$ & $\begin{array}{c}\text { Total } \\
\text { Domestik+Non } \\
\text { Domestik }\end{array}$ & $\begin{array}{c}\text { Kehilangan } \\
\text { Air }\end{array}$ & $\begin{array}{c}\text { Kebutuhan } \\
\text { Air Rata- } \\
\text { rata }\end{array}$ \\
\hline Satuan & $(1 /$ dtk $)$ & $(1 /$ dtk $)$ & $(1 /$ dtk $)$ & $(1 /$ dtk $)$ & $(1 /$ dtk $)$ \\
\hline \hline $\begin{array}{c}\text { Kecamatan } \\
\text { Binjai Barat }\end{array}$ & 67,837 & 13,567 & 81,404 & 16,2808 & 97,6848 \\
\hline $\begin{array}{c}\text { Kecamatan } \\
\text { Binjai Kota }\end{array}$ & 33,286 & 6,657 & 39,943 & 7,9886 & 47,9316 \\
\hline $\begin{array}{c}\text { Kecamatan } \\
\text { Binjai Selatan }\end{array}$ & 72,355 & 14,471 & 86,826 & 17,3652 & 104,1912 \\
\hline $\begin{array}{c}\text { Kecamatan } \\
\text { Binjai Timur }\end{array}$ & 84,999 & 17 & 101,999 & 20,3998 & 122,3988 \\
\hline $\begin{array}{c}\text { Kecamatan } \\
\text { Binjai Utara }\end{array}$ & 97,499 & 19,5 & 116,999 & 23,3998 & 140,3988 \\
\hline Kota Binjai & $\mathbf{3 5 5 , 9 7 6}$ & $\mathbf{7 1 , 1 9 5}$ & $\mathbf{4 2 7 , 1 7 1}$ & $\mathbf{8 5 , 4 3 4}$ & $\mathbf{5 1 2 , 6 0 5}$ \\
\hline
\end{tabular}




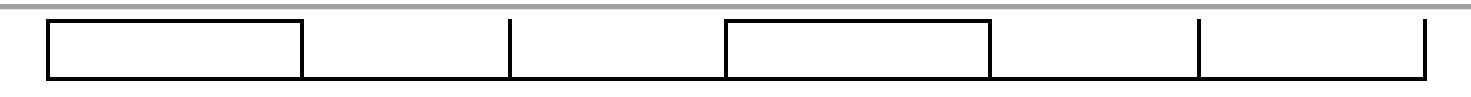

\subsection{Proyeksi Kebutuhan Air pada Jam Puncak Kota Binjai}

Pada Tabel dibawah ini berikut dapat dilihat perhitungan dan berapa besar kebutuhan air pada jam puncak serta kebutuhan harian maksimum di Kota Binjai terhitung mulai tahun 2018 dan 2025.

Tabel 17. Proyeksi Kebutuhan Air pada Jam Puncak pada Kota Binjai

\begin{tabular}{|c|c|c|}
\hline \multirow{2}{*}{ Tahun } & Kebutuhan Air & $\begin{array}{c}\text { Kota Binjai } \\
\text { (l/dtk) }\end{array}$ \\
\hline \hline \multirow{2}{*}{$\mathbf{2 0 1 8}$} & Harian Maksimum & 548,585 \\
\cline { 2 - 3 } & Pada Jam Puncak & 822,877 \\
\hline \multirow{2}{*}{$\mathbf{2 0 2 5}$} & Harian Maksimum & 615,126 \\
\cline { 2 - 3 } & Pada Jam Puncak & 922,689 \\
\hline
\end{tabular}

\section{KESIMPULAN DAN SARAN}

\section{KESIMPULAN}

1. Berdasarkan metode Geometrik dan metode Aritmatik, didapatkan proyeksi rata-rata jumlah penduduk kota Binjai pada tahun 2025 adalah 307,563 jiwa.

2. Proyeksi kebutuhan air minum domestik dan non-domestik pada tahun 2025 adalah $512,605 \mathrm{l} / \mathrm{dtk}$.

3. Proyeksi Kebutuhan Air pada Jam Puncak di Kota Binjai pada tahun 2025 adalah 922,689 1/dtk.

4. Total Kapasitas terpasang IPA Marcapada dan 3 sumur bor pada tahun 2019 adalah 195 1/dtk, sedangkan kapasitas produksinya adalah 155 lt/det.

5. Kota Binjai perlu pembangunan IPA yg baru untuk memenuhi target pemerintah yaitu seluruh masyarakat dapat terlayani air minum yang sehat dan terjangkau.

\section{DAFTAR PUSTAKA}

Asmadi, dkk. 2011., Teknologi Pengolahan Air Minum, Yogyakarta: Gosyen Publishing 
Ir.Sutrisno, T., dkk, 2010., Teknologi Penyediaan Air Bersih, Jakarta: Rineka Cipta

Kecamatan Binjai Barat Dalam Angka 2015-2019, Medan: Badan Pusat Statistik Sumatera Utara

Kecamatan Binjai Selatan Dalam Angka 2015-2019, Medan: Badan Pusat Statistik Sumatera Utara

Kecamatan Binjai Timur Dalam Angka 2015-2019, Medan: Badan Pusat Statistik Sumatera Utara

Kecamatan Binjai Utara Dalam Angka 2015-2019, Medan: Badan Pusat Statistik Sumatera Utara

Kota Binjai Dalam Angka 2015-2019, Medan: Badan Pusat Statistik Sumatera Utara 